\title{
River contract in Wallonia (Belgium) and its application for water management in the Sourou valley (Burkina Faso)
}

\author{
Rosillon $\mathrm{F}^{*}$, Vander Borght $\mathrm{P}^{*}$ and Bado Sama $\mathrm{H}^{* *}$ \\ * Department of Environment, University of Liège, 185 Avenue de Longwy, B 6700 Arlon, Belgium \\ (Email : f.rosillon@ulg.ac.be; vdborght@ful.ac.be) \\ **Convention pour la promotion d'un développement durable, 06BP9284, Ouagadougou 06, Burkina Faso \\ (Email : sgnanga@ hotmail.com)
}

\section{Référence à citer}

ROSILLON F., VANDER BORGHT P., BADO-SAMA H., 2005. River contract in Wallonia (Belgium) and its application for water management in the Sourou valley (Burkina Faso). Water Sciences and Technology, 52(9):85-93.

\begin{abstract}
Inspired from the experience of river contract in Wallonia (Belgium) since 1990, the implementation of a first river contract has been initiated in a West-African country, Burkina Faso. This application is not limited to a simple transposition of the Walloon model. The Burkina context calls to adaptation to the local environmental and socio-economical realities with an adequate partnership management.

The importance of the mobilization around this project of institutional partners, as well as local collectivities, agricultural producers and water users in general reveals the great expectations of the actors concerning this new tool of water participative management. But will the latter be equal to the task? A first assessment has been drawn up one year after the launching.

During the first year of the project, a participative diagnostic was implemented but the understanding basic notions of water management as "river" (not translate in the local language), "watershed", "contract" were not obvious. After the identification of functions and uses of water in the basin, an environmental survey was started. This approach allows to study with the river committees the priority actions to be developed as a first project of restoration of the gallery forest alongside the stream to fight against desertification.

This project of integrated and participative management of water at sub-basin level is a concrete example of solidarity and exchange know-how between North and South in the context of a sustainable development.
\end{abstract}

Keywords Burkina Faso, participative management, Sourou, Walloon Region, water.

\section{Introduction}

From Mar del Plata (1977) to Kyoto (2003), from forum to world summit and from water decade (in the eighties) to the fresh water international year (2003), the international community recognizes the importance of water for a sustainable development of humanity. In these meetings, the debate about the problems of water access and of sanitation could not be avoided, specially in developing countries. Sub-Saharian Africa is particularly concerned with a permanent hydric stress if not a deficit.

Through several praiseworthy statements such as the Social Charter of Water (Académie de l'eau, 2000), the "Chantier eau" of the Alliance for a responsible world open to solidarity (Bouguerra, 2000), the initiatives of the Global Water Partnership, the world water contract of the Lisbon group (Petrella, 1998), water is considered as a solidarity object. In his water manifest, R. Petrella (1998) considers water as the first common patrimonial property of humanity.

But the rushes of solidarity for the Southern countries lead to consider water problems do not only belong to the field of technicality. Similarly to sustainable development, water management needs a transversal approach with environmental, economical, social and cultural aspects. This kind of approach is possible when a participative water management is organized (Rosillon and Vander Borght, 2001). The "river contract" belongs to theses new methods of organization. Especially set up in Northern countries (Europe, Canada), this kind of management may bring one of the responses to the water problem in Southern countries. In Burkina Faso, a country of West-Africa, a first experience of river contract for the Sourou valley is being implemented in reference to the Walloon model. 


\section{Methods}

\section{The Walloon model of river contract}

Initiated in 1981 in France, the river contract has been carried out for more than a decade in the Walloon Region (Rosillon and Vander Borght, 2002). This model of decentralized participative management has been chosen in response to several problems and the request of water actors but also of civil society. Two of these new requests strengthened the desire for a new approach based on concerted action and consultation, namely :

- the increase of the number of water uses, especially in the recreational sector, which increased the pressure on the Region's water resources by creating user conflicts ;

- the population's increasing sensitivity to the various problems linked to water quality and environmental protection. This awareness, which has risen with the rising price of water, has led users and civil society to demand to participate in water resource decision-making.

A ministerial circular defines the river contract as "a protocol of agreement among all public and private players, concerning objectives aimed at striking a balance amongst the many functions and uses of watercourses, their approaches, and the water resources of the drainage basin". The river contract development approach consists of five phases (see figure 1.1). The partners committed to the contract are assembled in a river committee that decides, on the basis of consensus and without constraint, a program of actions to be carried out by each of the signatories of the contract in line with his responsibilities (Tricot et al., 2001). This voluntary approach considered as a gentlemen's agreement exists in parallel with extant legislation.

\begin{tabular}{|l|l|l|l|}
\hline PHASE & Length & $\begin{array}{l}\text { Entities } \\
\text { concerned }\end{array}$ & $\begin{array}{l}\text { Documents } \\
\text { generated }\end{array}$ \\
\hline $\begin{array}{l}\text { 1. START-UP } \\
\text { from } \\
\text { months to } \\
\text { year }\end{array}$ & $\begin{array}{l}\text { Initiator } \\
\text { Municipalities } \\
\text { Province(s) } \\
\text { Walloon Region }\end{array}$ & Preparatory file \\
\hline $\begin{array}{l}\text { 2. APPROVAL OF THE STUDY } \\
\text { AGREEMNT }\end{array}$ & 6 months & $\begin{array}{l}\text { Water Minister } \\
\text { Municipalities } \\
\text { Project's author } \\
\text { Appointee }\end{array}$ & Study agreement \\
\hline $\begin{array}{l}\text { 3. EXECUTION OF STUDY } \\
\text { AGREMENT }\end{array}$ & 3 years & $\begin{array}{l}\text { River Committee } \\
\text { (working parties) } \\
\text { Project's author }\end{array}$ & Draft river contract \\
\hline $\begin{array}{l}\text { 4. SIGNING OF THE RIVER } \\
\text { CONTRACT }\end{array}$ & 12 years max. & River Committee & River Contract \\
\hline 5. MONITORING & $\begin{array}{l}\text { Annual follow-up report } \\
\text { Review every three years }\end{array}$ \\
\hline
\end{tabular}

Figure 1.1 Steps in drawing up a river contract in the Walloon Region.

The river contract can be carried out if different conditions are put together : an adequate territorial space which generates a membership feeling, a federate item as a river, a common project, interactions between actors, knowledge to share and finally organization process with a space and participation structure (see figure $1.2)$.

With the sixteen ongoing projects, $43 \%$ of the territory of the Walloon Region and $48 \%$ of the Region's 262 municipalities are now concerned by a river contract. Among these projects, we find the contract of the river Semois, which has served as reference to export the Walloon model into Burkina Faso. 


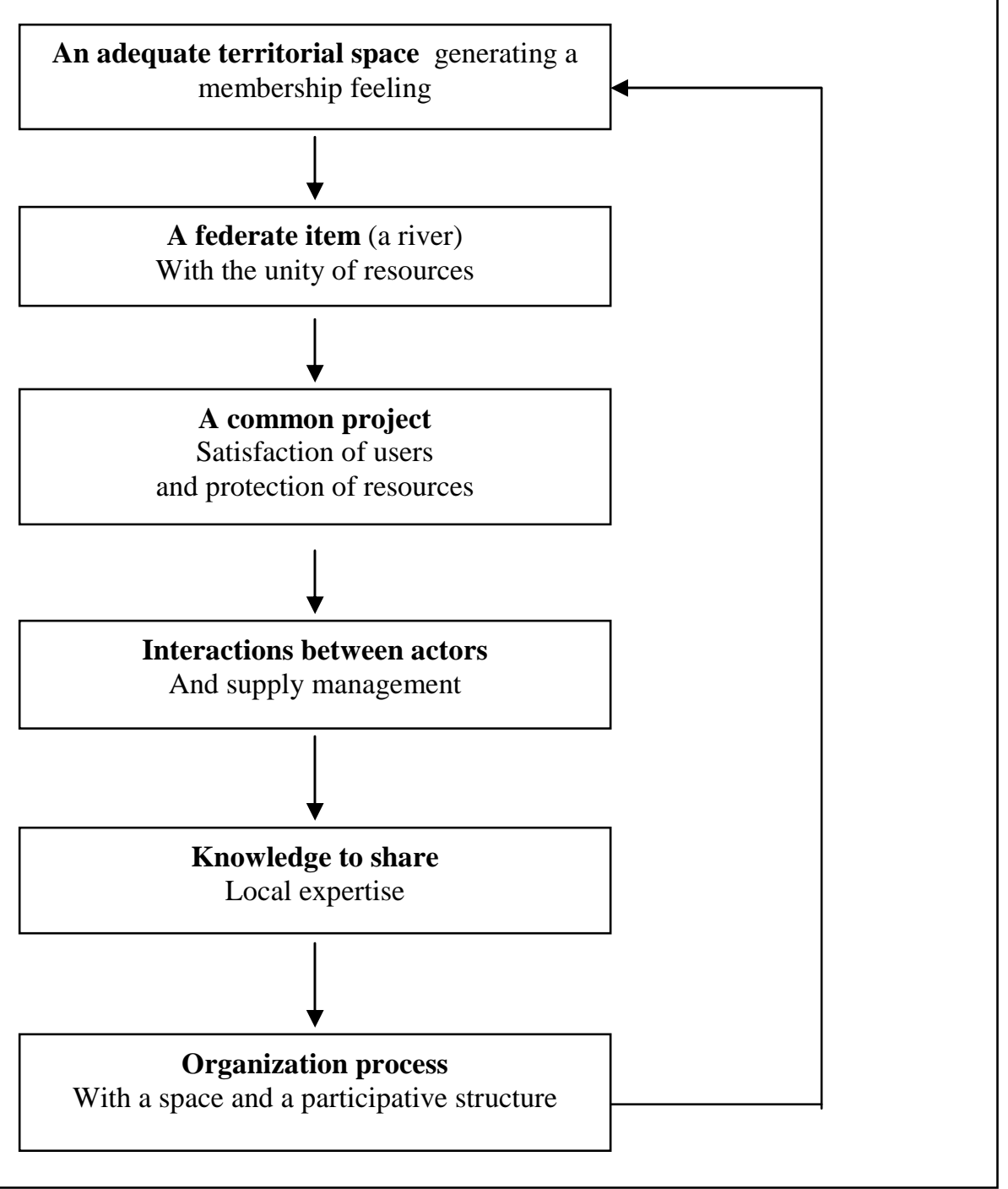

Figure 1.2 Conditions of a river contract in the water field

\section{When the Walloon model is exported in Burkina Faso}

In the context of the world meeting of Johannesburg, the Walloon Region would like to give its support to carry out the Agenda 21 for the benefit of developing countries. This wish has been translated in a project submission of decentralized cooperation.

This call notably devoted to the Walloon local collectivities has been accepted by four cities involved in the river contract on the Semois basin. As in 1993, when these cities asked the "Fondation Universitaire Luxembourgeoise", now become the Department of Environment of the University of Liège, to ensure the coordination of the Semois project, they required from the same institution the coordination of a river contract project in Burkina Faso.

This first project of river contract in West-Africa consists in an adaptation of the Walloon methodology of participative management of water resources in the developing countries with the case of the Sourou valley in Burkina Faso. On the spot, the animation and the coordination are carried out by a local NGO, the COPROD "Convention for the Promotion of a Sustainable Development) which already manages development projects in the environment field in Burkina Faso. The COPROD takes into account the local collectivities in the reflexion and research of adequate solutions, compatible with the surroundings potentialities. It favours the consultation and the participation of the whole of the actors of the integrated management of natural resources and promotes into the community a sustainable development dynamic on the base of a strong partnership.

The COPROD, after a training about the Walloon contract methodology during a formation in Belgium and a good knowledge of the water problem in the Sourou valley, proposed this catchment area as experimentation field (Bado Sama and Yéyé, 1999). 


\section{Burkina context}

Burkina Faso, continental country at the threshold of the Sahara, is located in the Centre of West Africa. It's a country with a very high hydric stress with a pluviometery of 600-900 mm per year and a Sahelian climate marked by a rainy season and a dry season. The essential of water resources is brought by rains during the July August period. Permanent water streams however are rare (CONAGESE, 2002). All the water streams are tributary of three international rivers namely the Niger, the Volta and the Canoé rivers. The Mouhoun, ex-black Volta, is the only permanent water stream. The Sourou river is one of its affluents. In this sub-basin with an area of 16,223 square kilometre, only the Sourou valley has been selected to manage the first river contract of Burkina Faso (see figure 1.3). This territory of 7,791 square kilometre counts 192,000 inhabitants distributed into 181 villages.

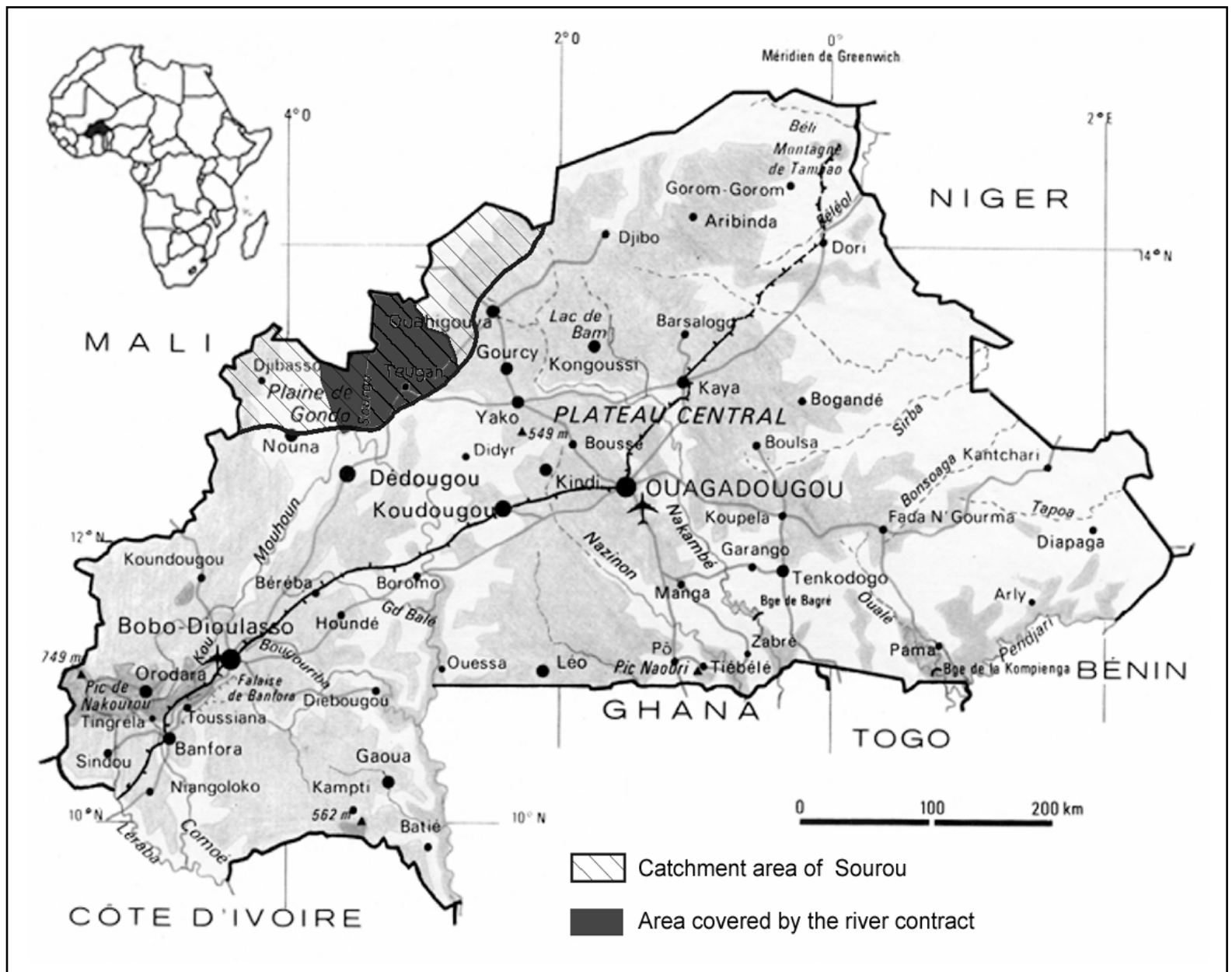

Figure 1.3 Area covered by the project : Sourou valley in Burkina Faso

Since the colonial age, this country has been the object of many hydro-agricultural managements. The agricultural station of Di was created in 1956. The Sourou valley has attracted populations from other Burkina's regions and neighbouring countries as Mali to research irrigated lands of permanent watercourse. This increase of population leads to an increase of uses and to a stronger pressure on water resources. To this, we should add risks of conflicting uses between different actors and the quantitative and qualitative damage on the resource with the threat of progressive disappearance of the river. Besides the environmental conditions particularly adapted to the implementation of a river contract, the socio-cultural aspects make up interesting assets too.

Nevertheless, a river contract fits into an institutional context. After the United Nations Summit of Environment and Development (PNUED) organized in Rio in June 1992, Burkina Faso adopted in July 99 his National Desertification Action Program (PAN-LCD). At the same time, the government started a decentralization policy and required from local collectivities the implementation of a Local Development Plan (PLD). This concern for decentralization on local level institutionally strengthened the relevance of a river contract in the Burkina context. The first PLD was elaborated for the Kassoum department in the Sourou 
province. The environmental and social conditions seemed gathered to install a project of river contract in WestAfrica.

This project stretches on a period of three years, from January 2003 to December 2005. It's not a simple transposition of the Walloon methodology. An adaptation with the local realities of the valley is necessary. This experience is organized in four stages : initialization of the project, river contract elaboration, implementation of actions program with demonstrative actions, assessment.

\section{Results and discussion}

\section{The outcomes of the river contract in Wallonia}

For 10 years, the analysis of the Walloon experiences has shown that the river contract is not limited to meetings without future. It produces social and environmental effects daily. A river contract starting point is based on the fact that the people express a feeling of belonging to a watercourse and cultural attachment to a valley and agree on a philosophy and future goals. By identifying the stakes, tensions, even sometimes conflicts, the users feel that they are concerned by water to the highest degree. The river contract makes it possible to transcend a one-time stake linked to a local water use in favour of a comprehensive drainage basin approach. The stakes and tensions are apprehended by all of the actors as a group. However, the river contract demands more than feeling concerned. The future partners must also subscribe to the consensus-building approach that it relies on.

On the environmental front, the contract gives birth to a holistic ecosystems approach and respect for the ecosystem completeness. This integrated management is achieved as soon as all of the representatives of the various sectors are included in the decision-making. The solutions that are adopted in the resulting action programmes allow for technical, natural, manmade landscape, social, and other aspects that come to light during the consensus-building phase.

The contract triggers new dynamism and motivations among the partners. Besides the improved knowledge and more frequent reliance on expertise that the river contract produces, it also contributes by giving rise to a range of new activities that reflect all of the assets included in the partnership. But, can we expect the same results with the experience implemented in the Sourou valley?

\section{Contributions and difficulties for a river contract in Burkina Faso}

The conditions to set up a river contract seem gathered at first sight in the Sourou valley : faced to a problem of sharing the water resources different actors are confronted to use conflicts (see figure 1.4). Moreover, in a country with acute water problems, experimenting participative management is attractive around a stream, which is a federative element of a whole region. Similarly to the Walloon Region, next to the institutional organization of water management, a local voluntary move can bring responses where traditional patterns lead to a dead end.

\section{Endangered river ...}

Some officials of the Environmental Ministry and local NGO say if no measure is taken in a twenty years' delay, the Sourou river is likely to lose its current status of permanent watercourse. But how can a river disappear after such a short time?

Next to the climate conditions unfavourable to a constant supply of water, add the human pressure that can accelerate the desert process. In the past, in order to raise the agrarian productivity of the valley, dams were erected in the bed of the river. The rise of the water level should create new possibilities of irrigation. The water has also flooded the natural gallery forest alongside the stream. Form of forest species do not resist flooding, this forest finally disappeared completely, leaving a bare soil instead.

In front of this big problem, remediation solutions are not obvious. A project of reinstallation of the gallery forest alongside the stream is nevertheless studied to reduce the soil erosion. This action, coordinated by the COPROD, with the collaboration of many partners engaged in the future river contract, should become one of the priority actions of this contract. 
During the first year of this project, a participative diagnostic was implemented. Information and awareness of local collectivities and users were possible by the organization of 22 meetings into 180 villages. After the identification of functions and uses of water in the basin, an environmental survey about hydraulic managements, ethno-botanical and breeding aspects was started. This approach allows to study with the river committees the priority actions to be developed as a first project of restoration of the gallery forest alongside the stream to fight against desertification.

Within the first weeks of launching the project, local populations were largely rallied to this initiative in which they put much hope. More than 1,000 people attended the launching ceremony and more than 5,000 people were present at the ceremony of constitution of the river committees. The same mobilization can be seen at all levels among all approached partners :

- institutional partners and central administration services in Ouagadougou;

- decentralized State services gathered in an already existing participative structure, the technical frame of coordination of the Sourou Province;

- the producer associations of the valley;

- the customary chiefs of the villages and the socio-cultural groups;

- the NGO.

This project also comes within a partnership with the CILSS (Interstate Committee of fight against the Drought in Sahel) which recognizes in this move, a means of fight against desertification. To this Burkinabe partnership corresponds a rush of solidarity in Wallonia. Through the implication of the Ministry of the Walloon Region and of four districts engaged in the contract of the Semois river, fruitful exchanges and a patronage of the Sourou contract by the Semois contract can be imagined.

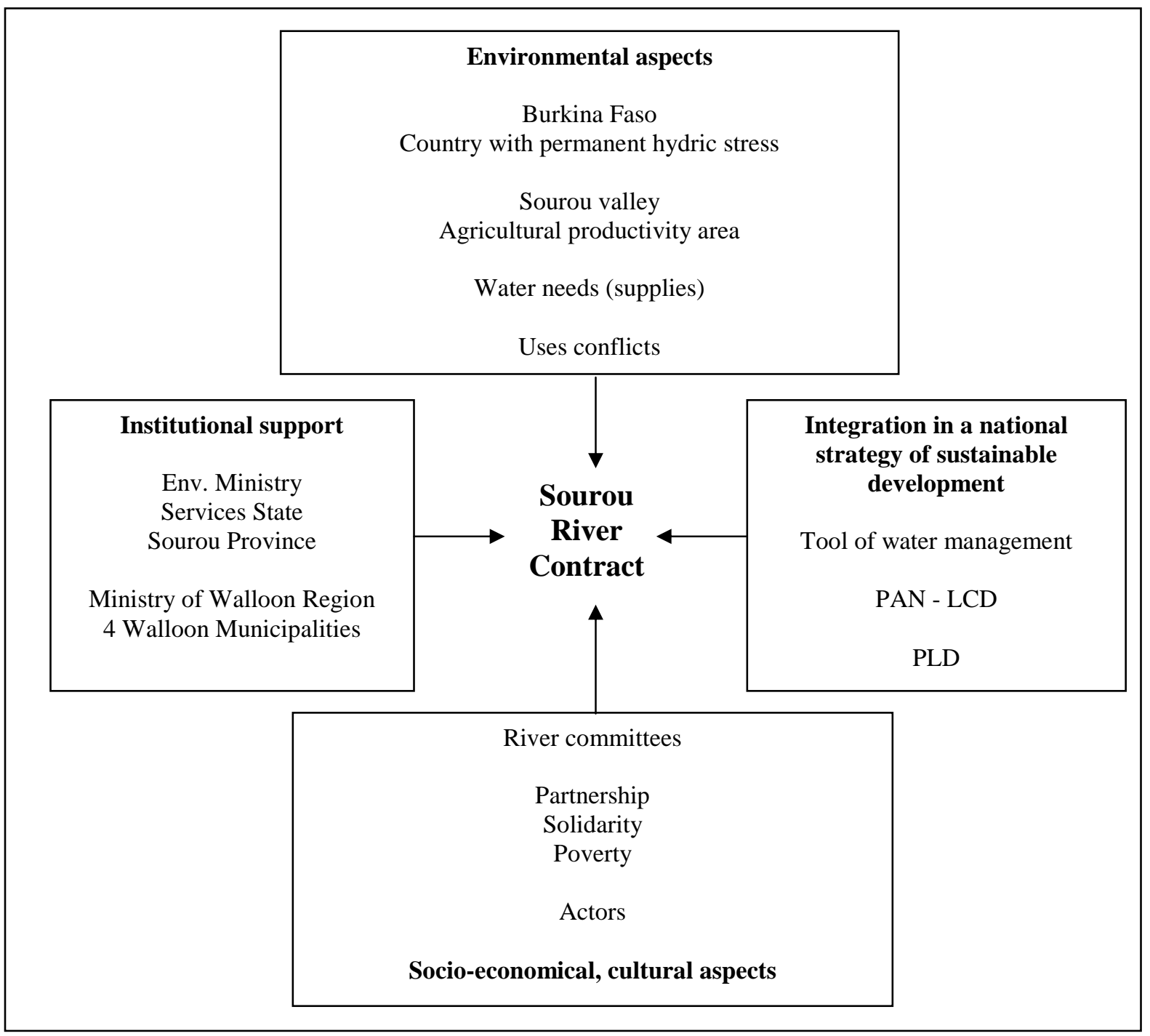

Figure 1.4 Implementation Frame of Sourou River Contract 
In spite of this favourable socio-cultural context, this project might meet difficulties such as understanding basic notions of water management well known in the West. Even the word "river" cannot always be translated in the local language and the notion of "contract" is very relative too. For a partly illiterate village population a written engagement between partners may not be the best formula. On the other hand the "given word" is very significant and taken seriously in this "country of upright men". This traditional form of engagement might favourably replace a written "contract".

Other environmental notions remain vague. What can the notion of "basin" mean in a country where most streams are temporary and where the relief only shows gentle slopes with limits of water divisions uneasy to visualize? The feeling of belonging of the local populations to this vast basin is for this reason very relative, as well as the meaning of up-or downstream relations.

On the other hand any environmental project leans on a certain knowledge. Scientific items are essential to set up an inventory of fixtures about the situation and make a diagnostic, to bring to the fore the problems which will be translated into objectives of management illustrated by a program of concrete actions. Without underestimating the traditional knowledge of the populations and the efforts of the State services, the availability and the acquisition of items might suffer from a lack of means and experts. This cross and multidisciplinary move will have to take place among a compartmentalized society as regards the numerous conventions and sectorial plans existing in Burkina.

In terms of partnership, at the time of setting up a participative structure called "river committee", it will be appropriate to pay attention to the legitimacy of the representatives. What will the missions of this committee be in front of or next to traditional or institutional management patterns deeply rooted in mentalities? A financial partnership should also be developed as well in order to gather sufficient means to set up a program of actions. But beside the direct supply of funds, it will be appropriate to encourage the contribution in work or in kind of the local collectivities and actors.

In front of these identified difficulties since the initialization stage, adequate solutions can be found. That does not prevent the continuation of the implementation of the project.

\section{Conclusions}

The Walloon Region's ten years of river contract experience has made it possible to assess how appropriate this tool is for sustainable water management based on locally organised participatory management. This voluntary approach considered as a gentlemen's agreement exists in parallel with extant legislation. This asset management approach applies primarily to the management of watercourses and aquatic environments which are considered to be part of a heritage to bequeath to future generations. Water is seen as a homogeneous element and a common asset of all of the actors.

This kind of approach can be applied in other countries, in the world. Since January 2003, an experience of adaptation of the walloon model in a developing country has been implemented. One year after being launched, the project of river contract in the Sourou valley is catching numerous admiring but also questioning eyes. This nice project is a concrete example of North-South solidarity in the field of water. By sharing a Walloon know-how and its adaptation to the Burkinabe realities, the challenge aims at improving the access to water and its management in a region which is submitted to a permanent stress about it. The great mobilization of institutions as well as citizens round this project and the numerous hopes of the local collectivities motivate the initiators who are nevertheless well aware of the difficulties to surmount. Among others, we will have to make sure local actors understand the methodology and basic environmental concepts correctly. It will also be important to set up the river committee and to make a real participative structure of it in favour of the water management in the Sourou valley. In front of sectorial management schemes confronted to the balance of power between users, the river committee will have to be recognized by all actors.

Short term priority is to stabilize the craze of the first months and to win the confidence of local partners. We will then have to demonstrate this type of move is not limited to discussions but that these negotiation and consensus stages are useful to lead to concrete realizations in a context of sustainable development in aid of citizens and users daily confronted to water problems. On the other hand, in terms of financial means, the Walloon partnership will have to be extended to other international sponsors, while developing the contribution of local partners. Eventually, following the example of the transboundary Semois/Semoy contract between France and Wallonia, we might contemplate a collaboration with Mali, sharing the Sourou river with Burkina.

Finally, in a country where the art of palaver and negotiation is widely spread, it is quite possible to think the step of river contract, whatever the name, could become an adequate management means in order to manage water better in West Africa. Display project in the sub-region, the river contract on the Sourou river 
could generate other similar initiatives, since participative management can be applied among others to the management of dam lakes, irrigated or shallow areas.

Anywhere on the planet Earth, as soon as some men and women are ready to gather to share their knowledge, their problems, their hopes and their motivation or dynamism about water problems, we think that a river contract can become reality.

\section{References}

Académie de l'eau. (2000) Social Charter for Water, a new approach to water management in the $21^{\text {st }}$ century. Water Agencies, Académie de l'eau, World water vision, 287p.

Bado Sama, H. and Yéyé, S. (1999) Le « contrat des rivières » peut-il contribuer à mieux gérer l'environnement burkinabé ? Arbre et Développement 24, 22-24.

Bouguerra, L. (2000) Une gouvernance mondiale adaptée aux défis du 21è siècle : la question de l'eau. Chantier EAU de l'Alliance pour un monde responsable et solidaire, Paris, 23 juin 2000, $8 \mathrm{p}$.

Petrella, R. (1998) Le manifeste de l'eau : pour un contrat mondial. Ed. Labor, Collection La Noria, Liège, 150p.

CONAGESE. (2002) State of Environment report for Burkina Faso. Secrétariat Permanent du Conseil National pour la Gestion de l'Environnement, Ouagadougou. 38p.

Rosillon, F. and Vander Borght, P. (2001) The River Contract in Wallonia: The Experience of a Governance Model in Water Management. Stockholm Water Symposium, 2001.

Rosillon, F. and Vander Borght, P. (2002) The Walloon model of participatory water management as assessed by the 10-year river contract experience. JEAPM Editor, World Scientific Publishing, http://www.worldscinet.com/jeapm/editorial/paper/4152541.doc , 12p.

Tricot, B., Lejeune, A., Nuttens, B., Rosillon, F., Vander Borght, P. (2001) Guide méthodologique relatif au contrat de rivière. MRW, DGRNE, Direction des Eaux de surface, $72 \mathrm{p}$.

Website on the river contracts in Wallonia : http://environnement.wallonie.be/contrat_riviere 